Mitteilungen der Österreichischen Geographischen Gesellschaft,

157. Jg. (Jahresband), Wien 2015, S. 253-276

\title{
Polish Spas in the Process of Transformation
}

\author{
Elżbieta GrZELAK-KostulsKa, Jadwiga BIEGAŃSKA, \\ Stefania ŚRODA-MurAWSKA, all Toruń, Poland, \\ and Adam SeNETRA, Olsztyn, Poland*
}

with 5 figures and 4 tables in the text

\section{CONTENTS}

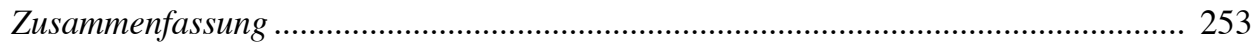

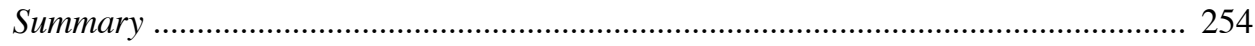

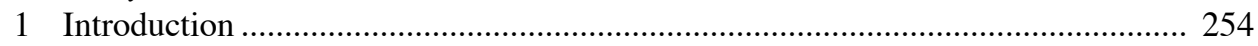

2 Spas in academic research ................................................................................. 255

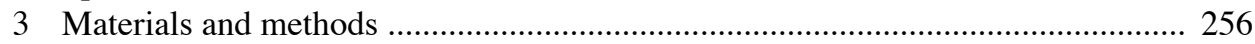

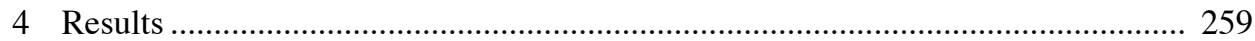

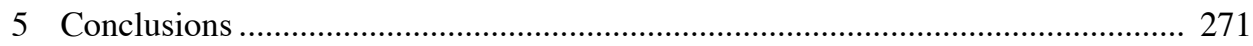

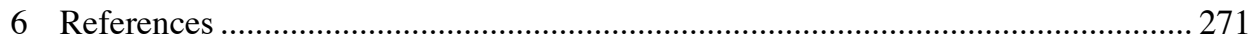

\section{Zusammenfassung}

Polnische Kurorte im Transformationsprozess

Der ökonomische Transformationsprozess, der in den ehemals kommunistischen Ländern Europas in den 1990er Jahren eingeleitet wurde, beeinflusste alle Lebensbereiche - auch die Tourismuswirtschaft. Abgewirtschaftete Kurorte in Staatsbesitz wurden in vieler Hinsicht transformiert, was unter anderem zum Wechsel des Eigentümers führte. Der Artikel beschäftigt sich mit dem Einfluss des Privatisierungsfortschritts auf die Fähigkeit der Kurorte die Unterstützung von EU-Fonds zu erreichen und bewertet ihn am Beispiel von 16 Kureinrichtungen in ähnlich großen Orten Polens. Er zeigt, dass eine geklärte Rechtsstellung den Unternehmen Stabilität verleiht und die wichtigste Voraussetzung für das Erreichen von EU-Unterstïtzung ist.

\footnotetext{
* Elżbieta Grzelak-Kostulska PhD, Jadwiga Biegańska PhD, and Stefania Środa-Murawska PhD, all Nicolaus Copernicus University in Torun, Faculty of Earth Sciences, Department of Urban Studies and Regional Development, Lwówska 1, PL-87-100 Toruń, Poland; email: grzelak@umk.pl; jadwigab@umk.pl; steff@ umk.pl; Adam Senetra PhD, University of Warmia and Mazury in Olsztyn, Department of Planning and Spatial Engineering, Prawocheńskiego 15, PL-10-724 Olsztyn, Poland; email: adam.senetra@uwm.edu.pl
} 
Schlagwörter: Kurorte, Systemtransformation, Privatisierung, Gesundheitstourismus, EUFörderungen, Polen

\section{Summary}

Economic transition initiated in the former Communist countries in Europe in the 1990s has had a strong impact on all spheres of life including tourism. Depreciated stateowned spas were subject to transformation resulting inter alia in ownership change. The article highlights and evaluates the relationship between progress in privatisation and ability to acquire EU funds by the example of 16 spas located in similar-sized settlements in Poland. It shows that a regulated legal status, thus providing companies with stability, has created optimal conditions for EU fundraising.

Keywords: spas, system transition, privatisation, health tourism, EU funds, Poland

\section{Introduction}

The development of spas is a complex phenomenon, but most of its determinants are well known. Some determinants, however, are less frequently referred to and appear under specific circumstances resulting from new conditions. In the countries of Central and Eastern Europe the key process contributing to the transformation of spas has been privatisation. But changes in spa profiles appeared not only in countries with a new economic model. As BUTLER (2010) notes, spas have often been prone to new trends, lost their primary goals or have returned to their basic functions (as, e.g., spas in Germany). The spas in Central and Eastern Europe have survived because they have maintained traditionally assigned roles. Nevertheless, change in external conditions resulting from economic transformation has increasingly involved them into contemporary prevention and wellness approaches. It seems that change in ownership and ability to acquire investment have determined the new directions.

Marketisation of the economy and commercialisation of services have set a new framework for the functioning of Polish spas. These processes have initiated a series of changes, which up to this day have inspired numerous discussions, comments and polemics, especially with regard to privatisation of state-owned spas. Main concerns are the limitation of statutory activity (i.e., spa treatment) in favour of an opening up to health tourism, which in fact has created a competitive and attractive offer.

In addition to functional diversification conditions for successful market adaptation were initiated by integration into the European Union (EU). Acquisition of external investment funds has significantly improved the conditions of many spas taking into account that their main problem had been under-investment into infrastructure (see Informacja o bieżącej sytuacji 2008). This has delayed privatisation and made it difficult, despite attempts to invest from the state budget (see Informacja o bieżącej sytuacji 2008).

The task of this article is on the one hand to evaluate privatisation of Polish spas and, on the other, to check the extent to which changes in ownership have contributed to an 
increased ability of acquiring EU funds. Hence, we will demonstrate the relationship between successful EU fundraising and privatisation in those Polish spas, which had previously been owned by the State Treasury.

We assume that regulated legal status, e.g., completed privatisation, has been conducive to acquiring external funds. We also assume that a consortium of spas is more successful in fundraising than individual companies and that geographical location plays a minor role in acquiring EU funds.

\section{Spas in academic research}

Spas located in many countries such as Japan ${ }^{1)}$, Turkey ${ }^{2)}$, the United Kingdom ${ }^{3)}$, Spain $^{4)}$, Slovenia $^{5)}$, Serbia $^{6)}$, Russia $^{7)}$, Estonia $^{8)}$, Romania $^{9)}$ and Poland ${ }^{10)}$ are subject of numerous studies. Most of them focus on the healing properties of their resources ${ }^{11)}$ and are connected with research in the fields of geology, geochemistry and hydrogeology. In the field of health sciences there are works in which attention is paid to the factors, which contributed to the establishment of spas in a particular place or to an analysis of the biographies of the spa's founders. ${ }^{12)}$

From an economic point of view it seems that the crucial factor is the presence of healing waters. ${ }^{13)}$ The operation of spas and the consequent development of tourism play an important role in the economy of many settlements ${ }^{14)}$ and rural areas ${ }^{15)}$ and as numerous studies show - in the economy of regions ${ }^{16)}$ and even of entire countries ${ }^{17)}$. Hence, in

1) See, e.g., Sekine, Nasermoaddeli, Wang, Kanayama \& Kagamimori 2006

2) See, e.g., Seckelmann 2002; ÖZKaynak 2008

3) See, e.g., Haley, Snaith \& Miller 2005

4) See, e.g., GonzÁlez, Comesaña \& Brea 2007; Pozo, Carretero, Maraver, Pozo, Gómez, Armijo \& Rubí 2013

5) See, e.g., GonzÁlez, Comesaña \& Brea 2007

6) See, e.g., Košić, Pivac, Romelić, Lazić \& Stojanović 2011; Joksimović \& Pavlović 2014

7) See, e.g., Vornov 2000; Bihari-Axelsson \& Axelsson 2002

8) See, e.g., Ahas, Aasa, Mark, Pae \& Kull 2007; Ahas, Aasa, Roose, Mark \& Silm 2008

9) See, e.g., Cooper, Fletcher, Noble \& Westlake 1995

10) See, e.g., KepinsKa 2003; KapCZyŃSKi \& SzromeK 2008; GrzelaK-KostulsKa 2012; Środa-MurawKSa 2012 ; GrZelak-Kostulska \& HoŁowiecka 2013

11) See, e.g., Freeston 1996; Samsudin, Hamzah, Rahman, Siwar, Mohd \& Othman 1997; Voronov 2000; Lund \& Freeston 2001; Árpási 2003; Dowgiallo \& Fistek 2003; Kepinska 2003; Lund 2003; Voronov \& VinogRad 2009; KozŁowska, Walencik, Dorda \& Zipper 2010; Walencik, KozŁowska, Dorda \& Zipper 2010; Lund, Freeston \& Boyd 2011; Igliński, Buczkowski, Kujawski, Cichosz \& Piechota 2012

12) See, e.g., Prunk, Azman, Frkovic, Skrobonja \& Muzur 2008

13) See, e.g., Bachvarov 1997; Özkaynak 2008; Košić, Pivac, Romelić, Lazić \& Stojanović 2011; Gössling, Peeters, Hall, Ceron, Dubois, Lehman \& Scott 2012; Joksimović \& Pavlović 2014

14) See, e.g., Środa-MurawsKa 2012

15) See, e.g., Iorio \& CoRsale 2010

16) See, e.g., Baidal 2003; Košić, Pivac, Romelić, Lazić \& Stojanović 2011; Joksimović \& Pavlović 2014

17) See, e.g., Baláž 1995; Bachvarov 1997; Coles 2003; Ahas, Aasa, Mark, Pae \& Kull 2007; Ahas, Aasa, Roose, Mark \& Silm 2008; Assaf \& Knežević Cvelbar 2011; Bihari-Axelsson \& Axelsson 2002; Dwyer, KneŽević Cvelbar, Edwards \& Mihalic 2012 
academic publications referring to spas in the context of tourism offer there are many discussions on the quality and diversity of tourism services offered ${ }^{18}$, on changing demands and opportunities to modify the offer ${ }^{19)}$ as well as on spa tourism as an important tourism product created in particular countries ${ }^{20)}$.

Spas in the countries of Central and Eastern Europe form a specific set. Their first stages were similar to those in Western Europe, where the precursors in the use of the healing properties of water were the ancient Romans. ${ }^{21}$ In the Middle Ages, the advantageous properties of water were forgotten and rediscovered only in the $17^{\text {th }}$ and $18^{\text {th }}$ centuries ${ }^{22)}$, when industrialisation and urbanisation began. Increased interest in spas emerged then from an increase in leisure time. Spas were no longer reserved for elites. ${ }^{23)}$ The following years, however, marked by the turbulent history of Central and Eastern Europe, led to separate developments in the two parts of Europe. After World War II, spas in Central and Eastern Europe underwent the rules of a Socialist economy ${ }^{24)}$ A quarter of a century since the fall of Communism, it is interesting to see how the economic situation of spas has changed and especially to inquire into their capacity to acquire EU funds.

\section{Materials and methods}

In Poland 45 spas were registered in 2014 (see Fig. 1). The Polish norm PN-Z11000:2001 on "Spas - terminology, classification and general requirements" [Uzdrowiska - terminologia, klasyfikacja i wymagania ogólne] offers the following classification with regard to altitude above sea level:

- lowland spas $-<300 \mathrm{~m}$;

- submontane spas - 300-500 m;

- mountain spas - 500-700 m;

- high-mountain spas ->700 m (currently there are none).

Most spas are located in the southern part of the country, although there are also some in northern Poland, mostly along the Baltic coast (see Fig. 1).

\footnotetext{
18) See, e.g., Omulecki, Nowak \& Zalewska 1996; SnoJ \& Mumel 2002; GonzÁlez, Comesaña \& Brea 2007

${ }^{19)}$ See, e.g., Cooper, Fletcher, Noble \& Westlake 1995; Chen, Liu \& Chang 2013

${ }^{20)}$ See, e.g., Hughes \& Allen 2005; Assaf \& Knežević Cvelbar 2011; Dwyer, Knežević Cvelbar, Edwards \& MinaLic 2012

21) See, e.g., Lund 1997; Petraccia, Liberati, Masciullo, Grassi \& Fraioli 2006; Pendlebury, Short \& While 2009; Carlino, Somma, Troise \& De Natale 2012

22) See, e.g., Routh, Bhowmik, Parish \& Witkowski 1996; Haley, Snaith \& Miller 2005; Hoppe, Janicka, Lerch \& Brübach 2008; Mayer, Müller, Woltering, Arnegger \& Job 2010; Jones 2013

${ }^{23)}$ See, e.g., Grose 2011

${ }^{24)}$ See Fletcher \& Cooper 1996; Light \& Dumbrăveanu 1999; Coles 2003
} 


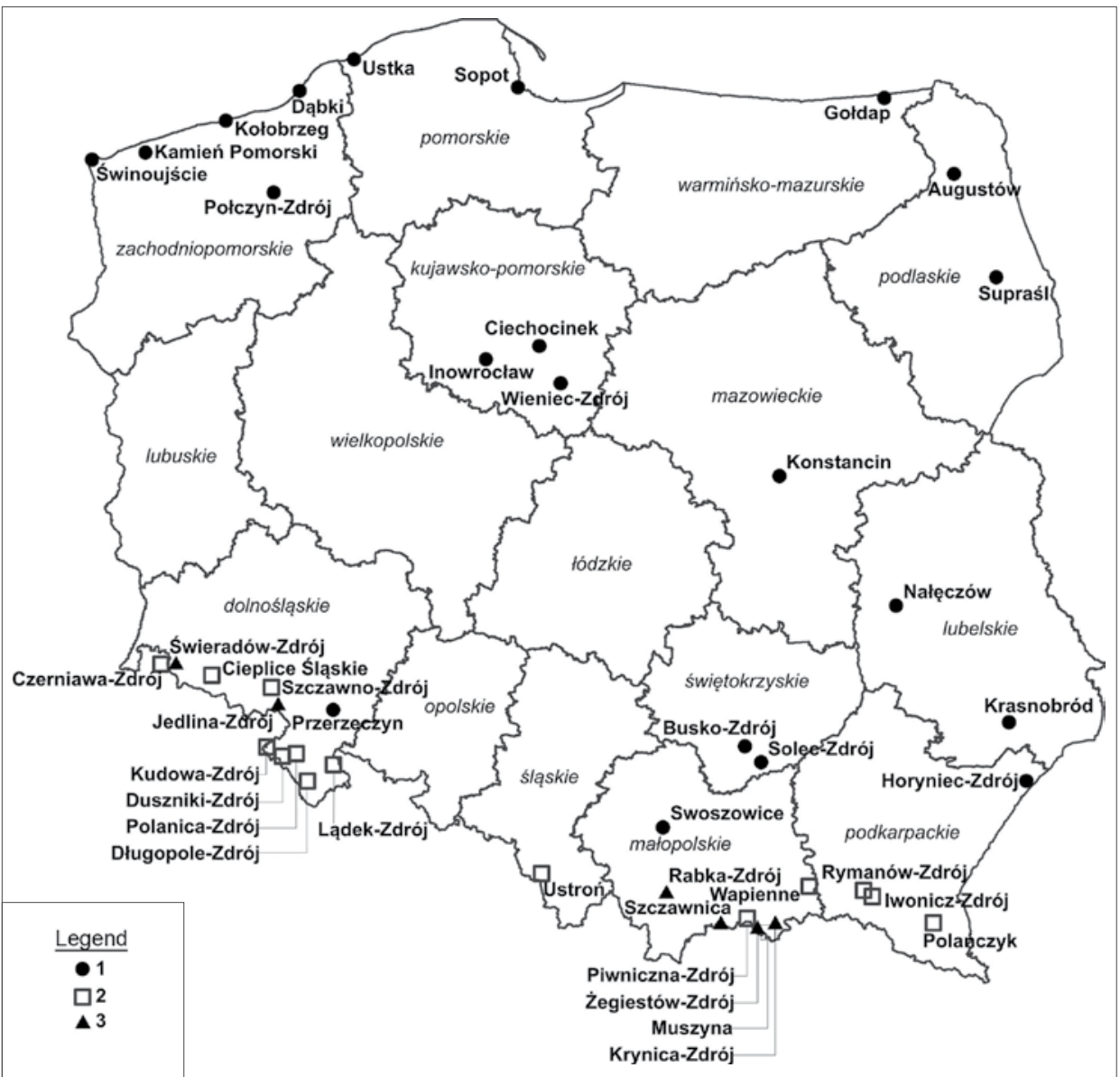

Source: authors based on Polish norm PN-Z-11000:2001

Fig. 1: Classification of spas according to altitude above sea level

26 of them are companies ${ }^{25)}$, which as former State Spa Enterprises [Państwowe Przedsiębiorstwa Uzdrowiskowe, PPU], the most important spa operation in post-war Poland, had been intended for privatisation. From this set we have analysed 16 (located in 22 settlements), i.e., more than $60 \%$ of all privatised companies, which according to the Act on the Privatisation of State Companies have been established as one-man companies of the State Treasury. Most of them had applied for privatisation between 1999 and 2001 and thus started the long process of ownership change.

\footnotetext{
25) Within the assumptions of privatisation set out, spa companies have been divided according to criteria based on their economic and financial situation, the policy of the National Health Fund [Narodowy Fundusz Zdrowia] in the field of contracts for the services of spa treatment and other factors. As a consequence of the process 23 spas have qualified for privatisation (HADZIK \& SZRomeK 2012).
} 
The set of selected spas has been limited to those located in similar-sized settlements, i.e., in small towns with a population of up to 20,000 . We have intentionally omitted large and medium-sized settlements as well as rural areas.

Geographical location has been another criterion: Spas analysed in this article represent three types differentiated by the Polish norm. They are situated in 9 out of 16 Polish voivodships [wojewódstwo], the highest subnational administrative level in Poland (see Fig. 1). This has ensured better comparability of the spas taken into consideration.

The spas analysed are very diverse in terms of ownership, and we have divided them into three main categories:

1. transferred without costs to a voivodship: Busko-Zdrój, Ciechocinek, Lądek-Długopole, Szczawno-Jedlina;

2. privatised:

a. belonging to the Polish Health Resorts Group [Polska Grupa Uzdrowisk, PGU]: the Kłodzko Spas [Zespół Uzdrowisk Kłodzkich], Połczyn-Zdrój, Świeradów-Czerniawa;

b. belonging to the BPS group of Polish Spas [Uzdrowiska Polskie, BPS]: IwoniczZdrój, Kamień Pomorski, Konstancin-Zdrój, Nałęczów;

c. managed by private owners: Szczawnica, Ustka, Ustroń;

3. exclusive property of the State Treasury:

a. in transition: Rabka;

b. excluded from privatisation: Krynica-Żegiestów (see Table 1).

Based on this categorisation we can state that the process of ownership change of the spas considered has in general been completed. The only exceptions are Rabka and Krynica-Żegiestów. The other companies have either been sold or transferred without costs to their voivodships. However, from the point of view of this research an important issue is the time, which has passed since ownership change. In many cases privatisation decisions coincided with the end of the 2007-2013 EU programme period. The companies were transferred to their voivodships. But we have not only taken into account spas that have been privatised earlier, we have analysed all those located in small towns and intended for privatisation over the entire period of ownership change.

The research has been conducted based on data derived from the official website of the Ministry of Infrastructure and Development. ${ }^{26)}$ The website had been created within a project co-financed from EU funds (European Regional Funds, Operational Programme - Technical Assistance). Information on the projects accepted by the EU Commission available at the website is currently being upgraded and monitored. The EU Grants Map has enabled the identification and location of the beneficiary and a full description of projects: title of application; area where the application has been implemented; operational programme, within which the application has been approved; level of financial support; total costs of the projects. We have also used data derived from the National Court Register [Krajowy Rejestr Sądowy]. ${ }^{27)}$

\footnotetext{
26) The EU Grants Map is available at: $h t t p: / / w w w . m a p a d o t a c j i . g o v . p l$

27) The Register is available at http://www.ems.ms.gov.pl/krs/wyszukiwaniepodmiotu
} 


\section{Results}

\subsection{Ownership change of spas}

Transformation in ownership of spas, which before the introduction of market changes had been units of the State Spa Enterprises, has undergone many stages. Some of them resulted from the complicated legal status of privatised assets. (By July 2009, e.g., the heirs of former owners had filed reprivatisation claims on the assets of nine spas.) (Informacja o wynikach kontroli 2010, p. 11). Others emerged due to the not too coherent approaches of the Ministry of State Treasury and the Ministry of Health. According to the report prepared by the Supreme Audit Office [Najwyższa Izba Kontroli] in 2010, "the Ministry of State Treasury changed the criteria for those spas, which should remain unprivatised" and "the Ministry of Health, with whom the list of spas was prepared, did not develop a clear position on those spas excluded from privatisation and accepted the proposals of the Ministry of State Treasury without conducting proper analyses of its impact on accessibility to spa treatment." (Informacja o wynikach kontroli 2010, p. 6).

Privatisation of Polish spas has widely been discussed in books (HADZIK, HADZIK \& Mikrut 2009; BoruszcZaK 2010), academic papers (WoŁowiec 2001, 2003, 2005; Burzyński, Golba, Pyka \& Szymańczyk 2004; Lewandowska 2007, 2008; Hadzik \& SZROMEK 2012; KAŹMIERCZAK 2013) and sectoral reports (Informacja o bieżącej sytuacji 2008; ŁACH \& RuTKOwsKa 2008, 2010; Informacja o wynikach kontroli 2010).

Economic transition in the early 1990s introduced new regulations. The first was the Act on the Privatisation of State Enterprises as of 13 July 1990, which was replaced by the Act on Commercialisation and Privatisation of State Enterprises as of 30 August 1996. A list of 26 spas, in which the tasks and competences of the founding body were taken over by the Ministry of Health and Social Welfare, was presented in the Regulation of 30 September 1996. It created a list of state-owned enterprises, in which the tasks and competences of the founding body are defined by government departments other than the Ministry of State Treasury and in which detailed rules and procedures for their taking over by voivodship governors or the Ministry of State Treasury are documented. However, by the end of 1998, when the conceptual framework for the commercialisation of State Spa Enterprises was formulated, the spas functioned as independent state units with a legal identity and with a varied legal status of asset ownership. Between 14 and 30 December 1998, according to a decision of the Ministry of State Treasury and after the Act on Commercialisation had been introduced, 17 joint-stock companies (JSC) and 9 limited liability companies (LLC) were established starting their activities between January and April 1999. Indirect privatisation with a disposal of shares to the public was implemented. The document entitled "Directions for the Privatisation of Treasury Assets" [Kierunki prywatyzacji majątku Skarbu Państwa] (Załącznik 2000) generally determined privatisation plans (but only qualitatively). However, this did not bring about a significant effect. Only one company was privatised, although as of 19 June 2002 the costs of privatising in the spa sector had amounted to 1,471,404 PLN (not including the privatisation costs of the Nałęczów Spa JSC [Zakład Leczniczy Uzdrowisko Nałęczów S.A.] paid for by the company) (Informacja o wynikach kontroli 2002). 


\begin{tabular}{|c|c|c|c|c|c|c|c|c|c|c|c|}
\hline 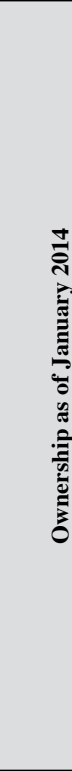 & & 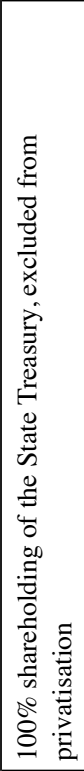 & 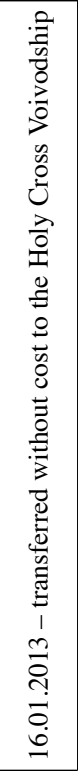 & 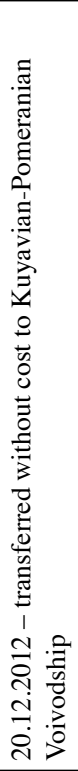 & 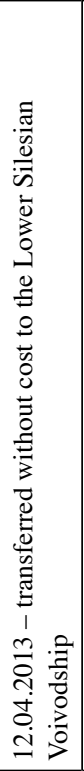 & 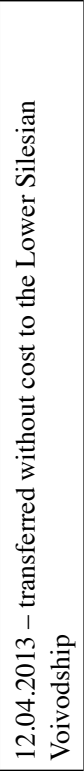 & 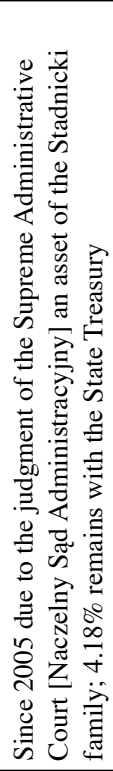 & 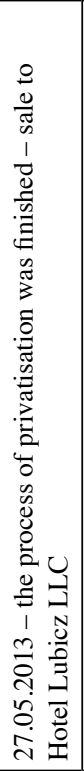 & 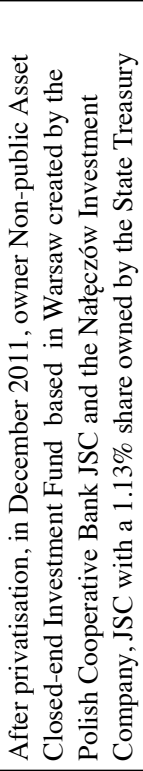 & 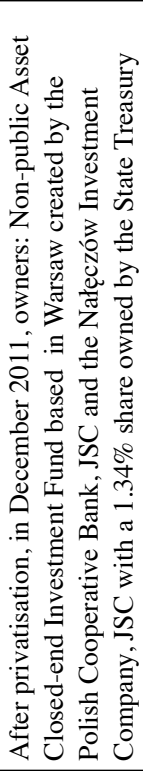 & 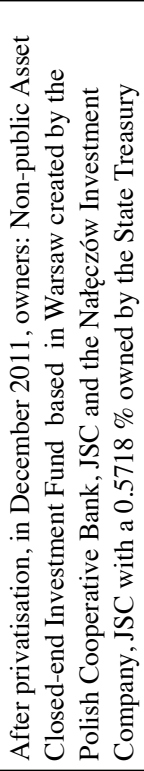 \\
\hline 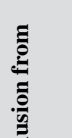 & 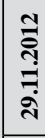 & & & & & & & & & & \\
\hline 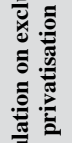 & 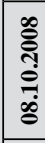 & & & & & & & & & & \\
\hline 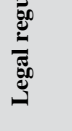 & 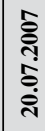 & & & & & & & & & & \\
\hline 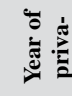 & & 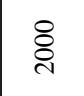 & 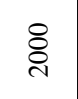 & 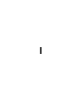 & ' & ¿্ণ & ठ্ণ & $\bar{\imath}$ & よे & ' & \&్ర \\
\hline 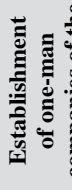 & & 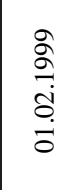 & $\begin{array}{l}\frac{2}{\sigma} \\
\frac{0}{0} \\
\end{array}$ & 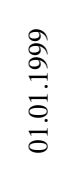 & 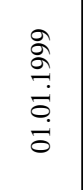 & $\begin{array}{l}\stackrel{\partial}{\sigma} \\
\frac{\sigma}{\delta} \\
\dot{\sigma}\end{array}$ & 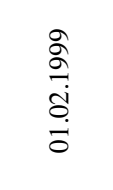 & 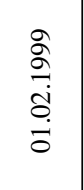 & $\frac{\stackrel{2}{\sigma}}{\stackrel{\circ}{\circ}}$ & 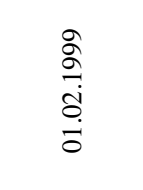 & 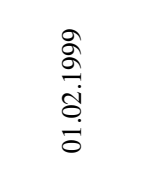 \\
\hline 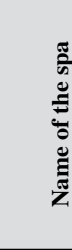 & & 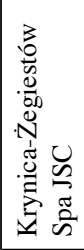 & 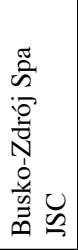 & 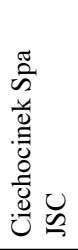 & 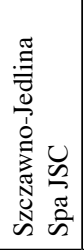 & 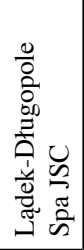 & 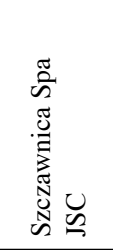 & 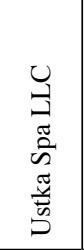 & 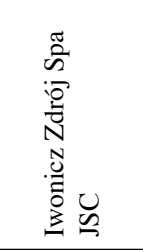 & 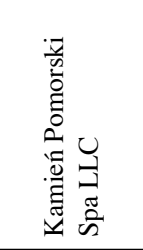 & 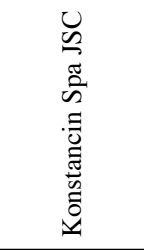 \\
\hline & & - & $N$ & $m$ & $\nabla$ & in & 0 & $r$ & $\infty$ & $a$ & 으 \\
\hline
\end{tabular}


Polish Spas in the Process of Transformation

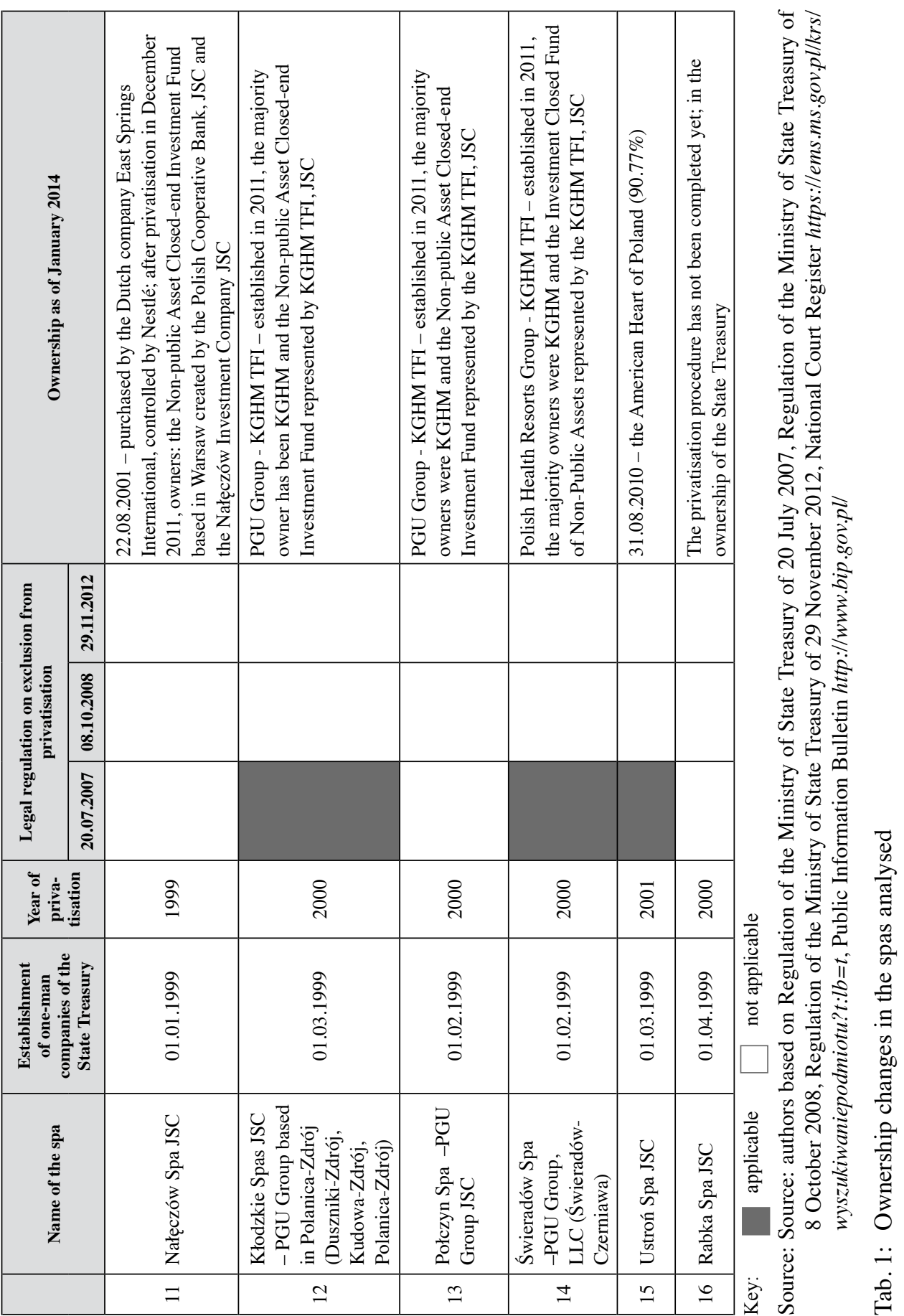


In 2002, privatisation procedures that had been initiated in 13 companies were halted due to a decision of the Ministry of Health until the Act on Spa Treatment, Spas and Areas of Spa Protection was accepted. A year later the Inter-ministerial Group for the Socio-economic Activation of Spas [Międzyresortowy Zespół ds. Aktywizacji Społeczno-Gospodarczej Uzdrowisk] began its work and set out an Integrated Programme for the Development of Spas [Zintegrowany program rozwoju uzdrowisk ze szczególnym uwzględnieniem usług turystycznych] (Zintegrowany Program 2005) with particular emphasis on tourism services and including the privatisation of spa treatment entities.

The accepted solutions, consistent with the new Act on Spa Treatment of 28 July 2005 , assumed that the companies would be divided into three groups:

- those excluded from privatisation (with special significance for spa treatment in Poland);

- those intended for privatisation, but with a five-year minimum period of majority shareholding by the State Treasury;

- those intended for full privatisation.

They were chosen to maintain the profile of spa activity and at the same time to raise funds for development. According to the Regulation of the Ministry of State Treasury of 20 July 2007, the first group included 14 companies (nine considered here) (Table 1). In 2008 , in the list annexed to the Regulation of the Ministry of State Treasury of 8 October 2008 only seven companies (with four here) were included. In 2012, it was accepted (according to the Regulation of the Ministry of State Treasury of 29 November 2012) that only the Krynica-Żegiestów Spa JSC was to be excluded from privatisation. The second group, i.e., spas controlled by the State Treasury, in fact ceased to exist within a year after introduction, the Ministry withdrawing from the five-year period its majority shareholding.

This (not too coherent) privatisation policy has not accelerated the difficult process of ownership change. Until 2010, only one spa had been sold (Nałęczów purchased by a Dutch company, i.e., East Springs International, in 2001.), while in 2005 Szczawnica Spa JSC [Przedsiębiorstwa Uzdrowisko Szczawnica S.A.] was returned to private ownership.

A breakthrough in the process of privatisation occurred only after 2010: In mid-2010, the enterprise American Heart of Poland gained a majority stake in Ustroń Spa JSC [Przedsiębiorstwo Uzdrowiskowe Ustron S.A.]. A year later, in 2011, the Polish Health Resorts Group - PGU [Polska Grupa Uzdrowisk, PGU] was formed, whose majority owner was KGHM and the Non-public Asset Closed-end Investment Fund [Fundusz Inwestycyjny Zamknięty Aktywów Niepublicznych] represented by KGHM TFI JSC. Spas included were Kłodzko Spas JSC [Uzdrowiska Kłodzkie S.A.] - a PGU Group based in Polanica-Zdrój, Połczyn Spa PGU Group JSC [Uzdrowisko Połczyn - Grupa PGU S.A.] and Świeradów Spa PGU Group LLC [Uzdrowisko Świeradów Sp. z o.o. - Grupa PGU].

In December 2011, the long process of privatising a further three spas was finished: Iwonicz-Zdrój Spa JSC [Uzdrowisko Iwonicz Zdrój S.A.], Kamień Pomorski Spa LLC [Uzdrowisko Kamień Pomorski Sp. z o.o.], Konstancin Spa LLC [Uzdrowisko Konstancin Sp. z o.o.]. In the case of Nałęczów Spa JSC a change of owner was noted. The new owner - as in the spas above - was the Non-public Asset Closed-end Investment Fund 
[Fundusz Inwestycyjny Zamknięty Aktywów Niepublicznych Uzdrowiska Polskie] based in Warsaw [Warszawa] and created by the Polish Cooperative Bank JSC [Bank Polskiej Spółdzielczości S.A.] and the Nałęczów Investment Company JSC [Nałęczowskie Towarzystwo Inwestycyjne S.A.] with some participation from the State Treasury.

Changes in the spas excluded from privatisation until 29 November 2012 (according to the Act of 8 October 2008) were slightly different. On $19^{\text {th }}$ September 2012, the Minister of State Treasury met representatives of relevant voivodship councils and proposed to transfer spa companies to them. In this way the Kuyavian-Pomeranian Voivodship [Województwo kujawsko-pomorskie] received the Ciechocinek Spa JSC [Przedsiębiorstwo Uzdrowisko Ciechocinek S.A.], the Holy Cross Voivodship [Województwo świętokrzyskie] the Busko-Zdrój Spa JSC [Uzdrowisko Busko-Zdrój S.A.] and the Lower Silesian Voivodship [Województwo dolnośląskie] the Szczawno-Jedlina Spa JSC [Szczawno-Jedlina S.A.] (privatised since 2008) as well as the Lądek-Długopole Spa JSC [Lądek-Długopole S.A.]. The governments of the voivodships were obliged to maintain the main field of activity, i.e., spa treatment, provide for the modernisation of infrastructure and solve other issues listed in detailed development plans of individual companies in subsequent years.

The last privatisation concerned the sale of Ustka Spa JSC [Uzdrowisko Ustka S.A.]. It was purchased by Hotel Lubicz LLC [Hotel Lubicz Sp. z o.o.] in 2013.

The companies totally owned by the State Treasury included only Krynica-Żegiestów Spa JSC [Uzdrowisko Krynica-Żegiestów S.A.], which is still formally excluded from any sale, and Rabka Spa JSC [Uzdrowisko Rabka S.A.], where the privatisation procedure has still to be completed.

\subsection{Ability of spas to acquire EU funds}

In our analysis based on information derived from the EU Grants Map we have considered two EU programme periods: 2004-2006 and 2007-2013. During these periods financial support amounting to $69,681,901.30$ PLN was acquired by the spas. (The total costs of the projects implemented amounted to $211,855,072.60$ PLN.) Within the two programme periods 20 projects were implemented, but only one in the 2004-2006 period.

More than half of EU funds $(54 \%)$ were acquired by spas the privatisation of which had been completed or which had finally been sold or transferred to the heirs of former owners - Category 2 (Fig. 2, Table 2). All companies in this category, except IwoniczZdrój, benefited from EU funds after ownership changes. The largest financial support (almost half of EU funds) was gained by Polish Spas BPS, mainly due to Nałęczów, which acquired investment totaling 57 million PLN. These funds were not intended, as usually, to improve infrastructure, they were devoted to 'research, development, innovation'. The share of EU financial support for the other spas privatised or sold was approximately $6 \%$ of the total value of all funds acquired by companies analysed (and 10\% of the total value of projects in spas).

In turn, one third of the total value of EU financial support acquired was received by four companies (Category 1) previously not intended for privatisation. The category does not include companies excluded from privatisation by the Acts of 2007 and 2008, i.e., until 29 November 2012 (Busko-Zdrój, Ciechocinek, Lądek-Długopole) and Szczawno-Jedli- 

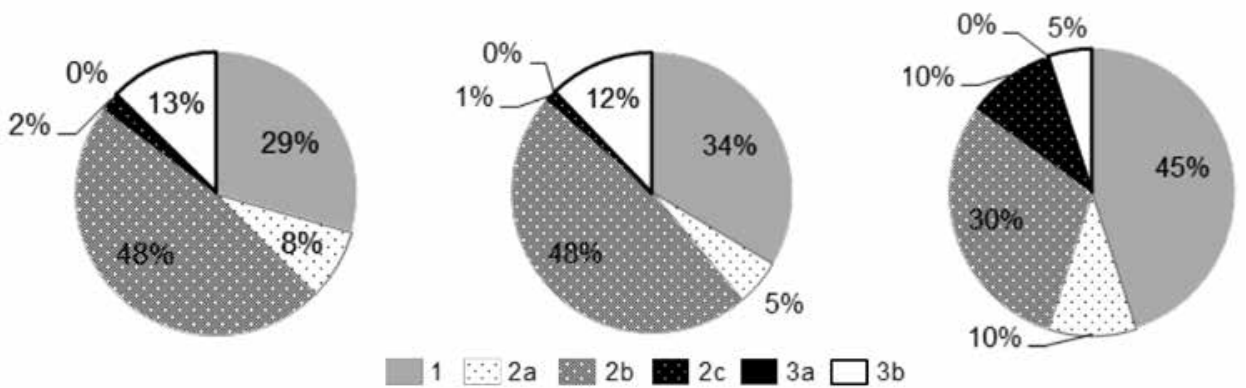

Key: Category of company: 1: transferred without costs to a voivodship (Busko-Zdrój, Cichocinek, Lądek-Długopole, Szczawno-Jedlina); 2: privatised: (a) the Polish Health Resorts Group (Kłodzko Spas, Połczyn-Zdrój, Świeradów-Czerniawa), (b) the group of Polish Spas BPS (Iwonicz-Zdrój, Kamień Pomorski, Konstancin-Zdrój, Nałęczów), (c) managed by a private owner (Szczawnica, Ustka, Ustron); 3: exclusive property of the State Treasury: (a) in transition (Rabka), (b) excluded from privatisation (Krynica-Żegiestów).

Source: authors based on EU Grants Map http://www.mapadotacji.gov.pl/

Fig. 2: Projects implemented in the context of ownership status of the spas analysed

na, which had not been subject to privatisation until 8 October 2008. (The Act of 2007 regulated its status.) The spas showed significant activity in applying for EU funds and implemented nine projects. The funds acquired amounted to 23,353,704.97 PLN, and the total value of the projects implemented reached 62,207,385.86 PLN. However, in their case applications for EU funds had been submitted and implemented before they had been transferred to voivodships, i.e., at the end of 2012 and the beginning of 2013. Hence, we could not evaluate the impact of ownership change on the ability to raise EU funds. They were rather co-financed in this way (in addition to the state budget) to strengthen the position of these companies offered by the Ministry of State Treasury to successfully complete their privatisation. Significant funding was also acquired by Krynica-Żegiestów (12\%) - the only company that continued to be excluded from privatisation by the Act of 29 November 2012. In this case the value of financial support was much higher than the average. Relatively little support (1\%) was acquired by companies sold to private owners (Szczawnica and Ustron) receiving less than one million PLN.

In order to compare the financial support acquired from the EU by the spas considered we had to find some objective indicators. As a point of reference we used the value of company capital (determined by their entry in the National Court Register). It is worth mentioning that among these spas more than half of the total capital was held by companies sold (Category 2). More than $22 \%$ of the total capital belonged to PGU - KGHM TFI, approximately $15 \%$ to Polish Spas BPS and less than $19 \%$ to private owners. One quarter of the total capital was held by companies transferred to voivodships: to the Holy Cross, Kuyavian-Pomeranian and Lower Silesian voivodships. The State Treasury managed the capital of the Rabka and Krynica-Żegiestów spas (19\%). 


\begin{tabular}{|c|c|c|c|c|}
\hline & Category of spa (companies) & $\begin{array}{l}\text { Total value of } \\
\text { projects }[\text { PLN] }\end{array}$ & $\begin{array}{l}\text { Financial } \\
\text { support from the } \\
\text { EU }[\text { PLN }]\end{array}$ & $\begin{array}{l}\text { Number } \\
\text { of } \\
\text { projects }\end{array}$ \\
\hline 1 & Busko-Zdrój Spa JSC & $27,428,306.30$ & $9,743,438.10$ & $3 *$ \\
\hline 1 & Ciechocinek Spa JSC & $8,637,749.00$ & $6,582,372.70$ & 2 \\
\hline 1 & Szczawno-Jedlina Spa & $16,534,379.10$ & $4,482,109.60$ & 2 \\
\hline 1 & Lądek-Długopole Spa JSC & $9,606,951.50$ & $2,545,784.70$ & 2 \\
\hline 1 & $\begin{array}{l}\text { transferred without costs to } \\
\text { voivodships - total }\end{array}$ & $62,207,385.90$ & $23,353,704.90$ & 9 \\
\hline $2 \mathrm{a}$ & $\begin{array}{l}\text { Kłodzkie Spas JSC - PGU Group based } \\
\text { in Polanica-Zdrój (Duszniki-Zdrój, } \\
\text { Kudowa-Zdrój, Polanica-Zdrój) }\end{array}$ & 0 & 0 & 0 \\
\hline $2 \mathrm{a}$ & Połczyn Spa - PGU Group JSC & $7,606,593.30$ & $2,380,046.10$ & 1 \\
\hline $2 \mathrm{a}$ & $\begin{array}{l}\text { Świeradów Spa - the PGU Group, LLC } \\
\text { (Świeradów-Czerniawa) }\end{array}$ & $9,769,232.50$ & $1,353,327.50$ & 1 \\
\hline $2 \mathbf{a}$ & PGU Group - total & $17,375,825.80$ & $3,733,373.60$ & 2 \\
\hline $2 b$ & Iwonicz Zdrój Spa JSC & $7,763,236.70$ & $3,848,866.80$ & 2 \\
\hline $2 b$ & Kamień Pomorski Spa LLC & 0 & 0 & 0 \\
\hline $2 b$ & Konstancin Spa JSC & $36,068,013.80$ & $7,493,028.10$ & 1 \\
\hline $2 b$ & Nałęczów Spa JSC & $57,237,762.50$ & $21,766,283.10$ & 3 \\
\hline $2 \mathbf{b}$ & BPS - total & $101,069,012.90$ & $33,108,178.10$ & 6 \\
\hline $2 \mathrm{c}$ & Szczawnica Spa JSC & $885,600.00$ & $183,600.00$ & 1 \\
\hline $2 \mathrm{c}$ & Ustka Spa LLC & 0 & 0 & 0 \\
\hline $2 \mathrm{c}$ & Ustroń Spa JSC & $3,438,363.60$ & $803,044.70$ & 1 \\
\hline $2 \mathbf{c}$ & Managed by a private owner - total & 4,323,964.00 & $986,644.70$ & 2 \\
\hline 2 & Privatised companies $(2 a+2 b+2 c)$ & $122,768,802.70$ & $37,828,196.40$ & 10 \\
\hline $3 \mathrm{a}$ & Rabka Spa JSC & 0 & 0 & 0 \\
\hline $3 b$ & Krynica-Żegiestów Spa JSC & $26,878,884.00$ & $8,500,000.00$ & 1 \\
\hline \multirow[t]{2}{*}{3} & Property of the State Treasury & $26,878,884.00$ & $8,500,000.00$ & 1 \\
\hline & Total & $211,855,072.60$ & $69,681,901.30$ & 20 \\
\hline
\end{tabular}

Key: see Fig. 2

(* including one for 2004-2006)

Source: authors based on EU Grants Map http://www.mapadotacji.gov.pl/

Tab. 2: Projects implemented from EU funds by spas analysed according to ownership 
Comparison of the value of financial support, the value of projects implemented and the value of spa capital enabled us to better assess the advantages achieved in particular groups of companies (Table 3, Fig. 3, 4). The indicators show that the best effects were

\begin{tabular}{|c|c|c|c|c|c|}
\hline $\begin{array}{c}\text { Cate- } \\
\text { gory } \\
\text { of spa }\end{array}$ & $\begin{array}{c}\text { Value of project } \\
\text { [PLN] } \\
\mathbf{A}\end{array}$ & $\begin{array}{c}\text { Value of financial } \\
\text { support [PLN] } \\
\mathbf{B}\end{array}$ & $\begin{array}{c}\text { Value of company } \\
\text { capital [PLN] } \\
\mathbf{C}\end{array}$ & $\begin{array}{c}\mathbf{W P} / \mathbf{K} \\
\mathbf{A} / \mathbf{C}^{*} \mathbf{1 0 0}\end{array}$ & $\begin{array}{c}\mathbf{D} / \mathbf{K} \\
\mathbf{B} / \mathbf{C} * \mathbf{1 0 0}\end{array}$ \\
\hline 1 & $62,207,385.90$ & $23,353,705.00$ & $82,320,000.00$ & 75.6 & 28.4 \\
\hline $2 \mathrm{a}$ & $17,375,825.80$ & $3,733,373.60$ & $72,771,710.00$ & 23.9 & 5.1 \\
\hline $2 \mathrm{~b}$ & $101,069,012.90$ & $33,108,178.00$ & $49,564,160.00$ & 203.9 & 66.8 \\
\hline $2 \mathrm{c}$ & $4,323,964.00$ & $986,644.70$ & $61,050,000.00$ & 7.1 & 1.6 \\
\hline $3 \mathrm{a}$ & 0.00 & 0.00 & $21,300,000.00$ & 0.0 & 0.0 \\
\hline $3 \mathrm{~b}$ & $26,878,884.00$ & $8,500,000.00$ & $41,720,000.00$ & 64.4 & 20.4 \\
\hline
\end{tabular}

Source: authors based on EU Grants Map http://www.mapadotacji.gov.pl/ (as of 24 April 2014) and the National Court Register http://www.ems.ms.gov.pl/krs/wyszukiwaniepodmiotu (as of 7 March 2014)

Tab. 3: Value of projects and value of financial support in relation to the value of company capital according to category of spas analysed

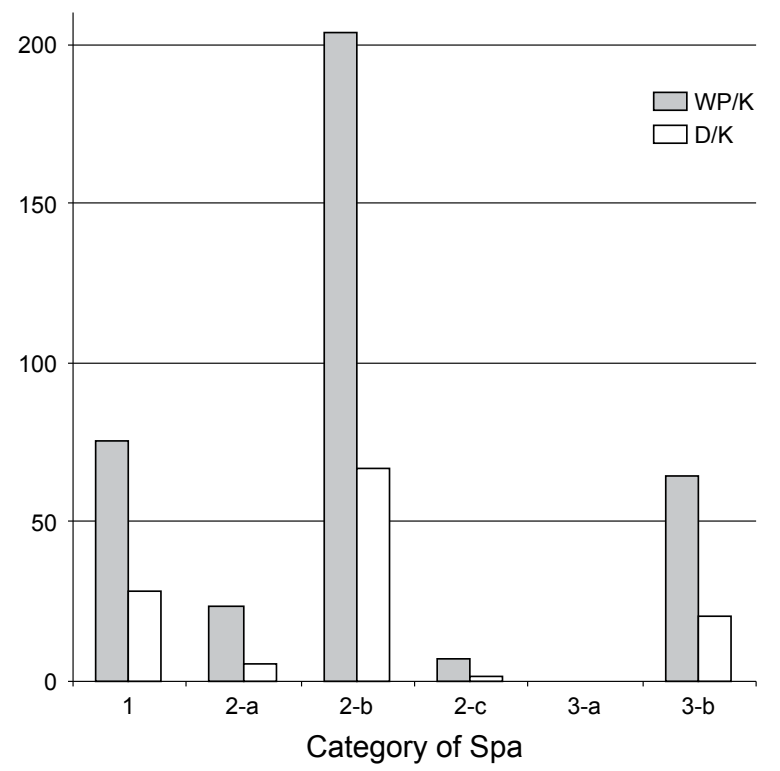

Key: see Table 3

Source: authors based on EU Grants Map http://www.mapadotacji.gov.pl/

Fig. 3 Value of projects and value of financial support in relation to the value of company capital according to category of spas analysed 


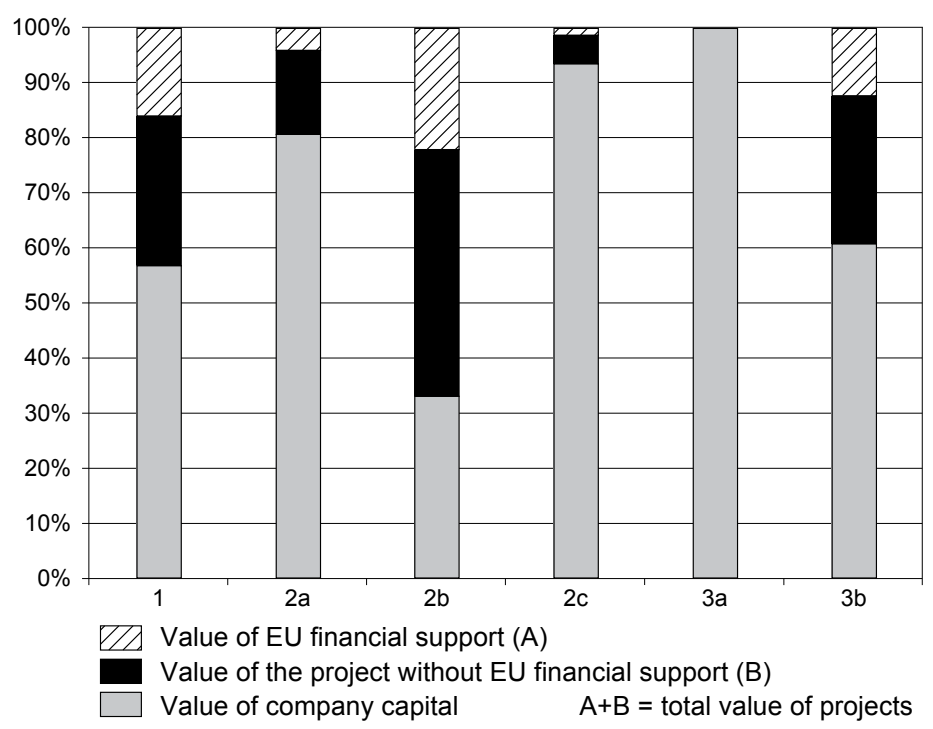

Key: see Table 3

Source: authors based on EU Grants Map http://www.mapadotacji.gov.pl/

Fig. 4: Comparison of the value of company capital with the total value of projects and EU financial support according to category of spas analysed

achieved by privatised companies (Category 2), especially Polish Spas BPS. The value of financial support reached $67 \%$ of the companies' capital value and the value of projects exceeded it twice. The companies owned by the State Treasury during the programme periods acquired funds at a level of $20-30 \%$ of their capital. The exception is Rabka, which has still to implement a project and is still waiting for final decisions concerning ownership.

We have also analysed the ability of spas to acquire EU funds in the context of their geographical location according to the Polish norm PN-Z-11000:2001 (Tab. 4, Fig. 5). Considering this factor, lowland resorts proved to be most active acquiring 7 million PLN from EU funds per spa with the total value of all projects in a single spa amounting to almost 20 million PLN. If we remove from the lowland type those spas located at the seaside, which did not implement any project in the period analysed, then the results are 10 and 27 million PLN, respectively. Submontane spas acquired the lowest amount of EU funds: Although each of them implemented one project on average, the total value of EU funding was only 1.5 million PLN, and the average total value was 3.7 million PLN. Similar mean funding figures and total values of projects (despite some differences in their number) were noted in submontane-mountain and mountain resorts, which received on average 3 million PLN funding per project with the average overall value approaching 10 million PLN.

It seems that the main factors affecting the value of financial support acquired are first of all the type of ownership and then the type of the project. As we have mentioned, most 


\begin{tabular}{|c|c|c|c|c|c|c|c|c|c|c|c|c|c|c|c|}
\hline 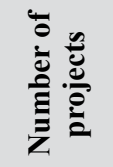 & $\stackrel{*}{m}$ & 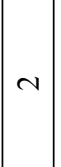 & - & $m$ & - & 0 & 0 & 은 & $\stackrel{+}{-}$ & 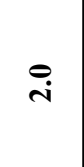 & 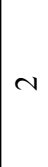 & 0 & - & $\infty$ & $\stackrel{\ominus}{\circ}$ \\
\hline 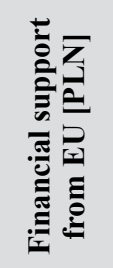 & $\begin{array}{l}\stackrel{0}{\leftarrow} \\
\infty \\
\stackrel{\infty}{*} \\
\stackrel{\sigma}{\sigma} \\
\stackrel{\sigma}{\sigma}\end{array}$ & $\left|\begin{array}{c}0 \\
\tilde{N} \\
\tilde{n} \\
\tilde{N} \\
\infty \\
n \\
0\end{array}\right|$ & 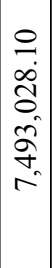 & 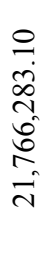 & $\begin{array}{l}0 \\
0 \\
0 \\
0 \\
0 \\
0 \\
\infty \\
m \\
i \\
\text { in }\end{array}$ & 0 & 0 & 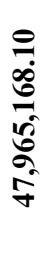 & $\left|\begin{array}{c}\hat{0} \\
0 \\
\dot{0} \\
0 \\
\hdashline \\
\hat{n} \\
0 \\
0 \\
0\end{array}\right|$ & 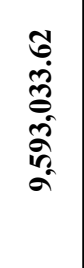 & $\begin{array}{l}\infty \\
\infty \\
\dot{0} \\
\infty \\
\infty \\
\infty \\
\infty \\
\infty \\
\infty \\
\text { m }\end{array}$ & 0 & 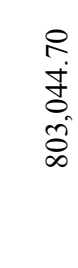 & 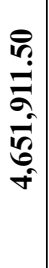 & 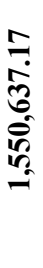 \\
\hline 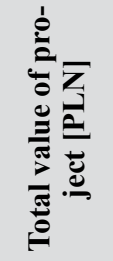 & 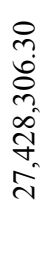 & $\left|\begin{array}{c}8 \\
0 \\
\dot{+} \\
\tilde{T} \\
\hat{2} \\
0 \\
\infty \\
\infty\end{array}\right|$ & 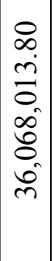 & 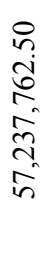 & 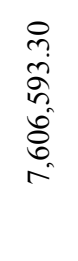 & 0 & 0 & 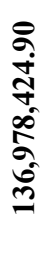 & $\begin{array}{c}7 \\
\dot{0} \\
0 \\
0 \\
0 \\
0 \\
0 \\
0 \\
0 \\
0\end{array}$ & 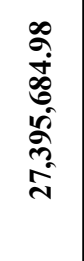 & 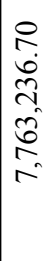 & 0 & 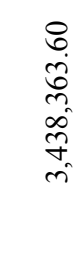 & 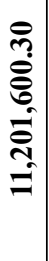 & 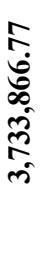 \\
\hline 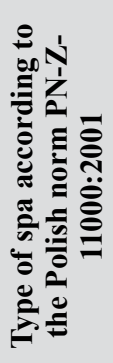 & $\begin{array}{l}\overrightarrow{\vec{E}} \\
\frac{\vec{z}}{3} \\
\underline{0}\end{array}$ & 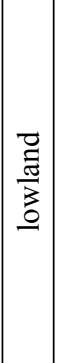 & 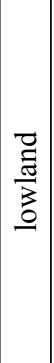 & $\begin{array}{l}\text { 믈 } \\
\frac{\pi}{3} \\
0\end{array}$ & $\frac{7}{\overrightarrow{0}}$ & 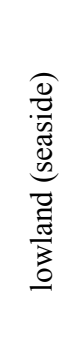 & 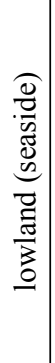 & 总 & 它 & 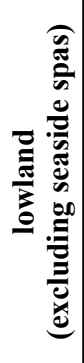 & 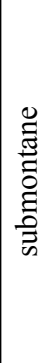 & 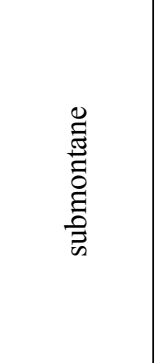 & 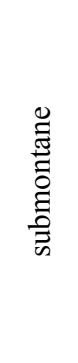 & 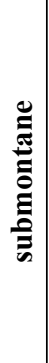 & 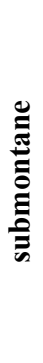 \\
\hline 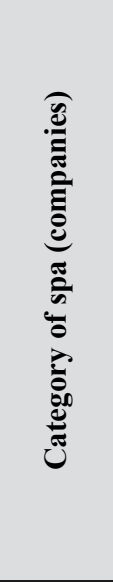 & 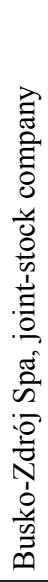 & 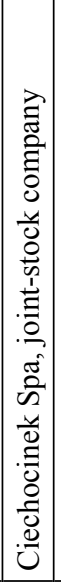 & 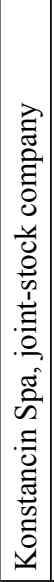 & 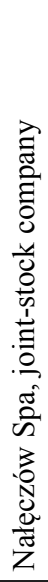 & 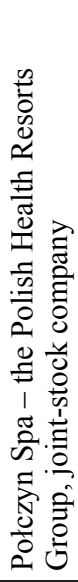 & 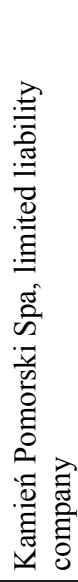 & 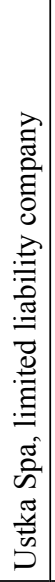 & 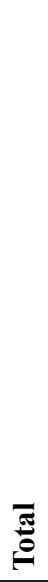 & 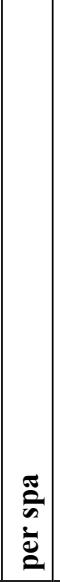 & 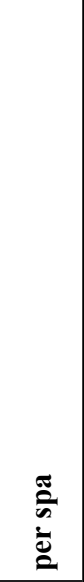 & 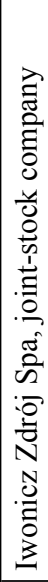 & 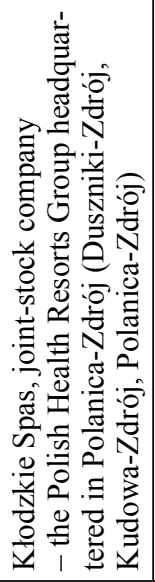 & 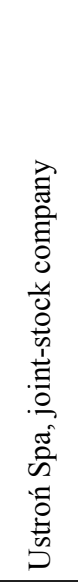 & సี & $\begin{array}{l}\text { : } \\
\bar{n} \\
\vdots \\
\vdots\end{array}$ \\
\hline & - & - & - & - & - & - & - & & & & N & 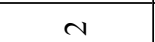 & $N$ & & \\
\hline
\end{tabular}




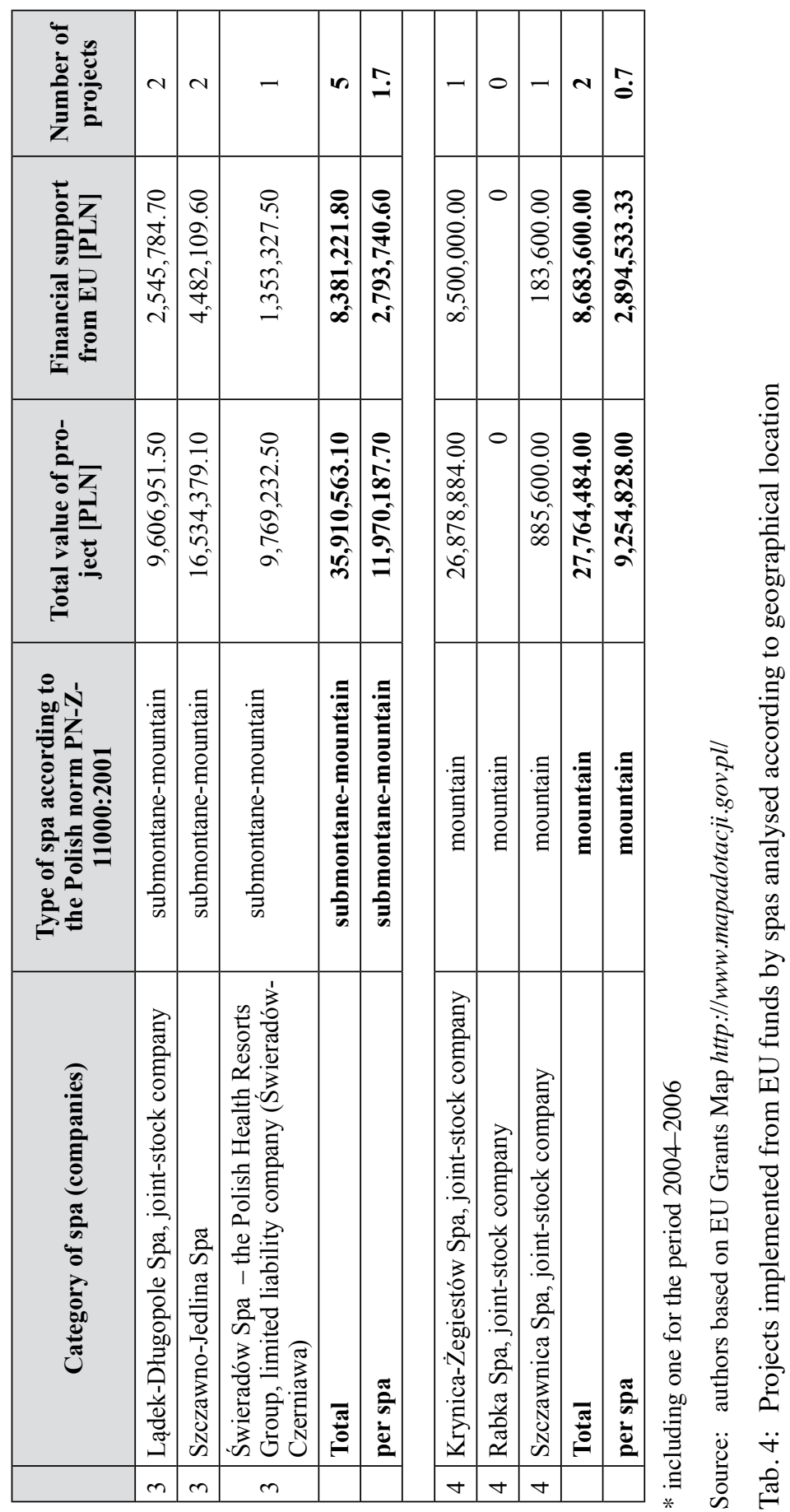




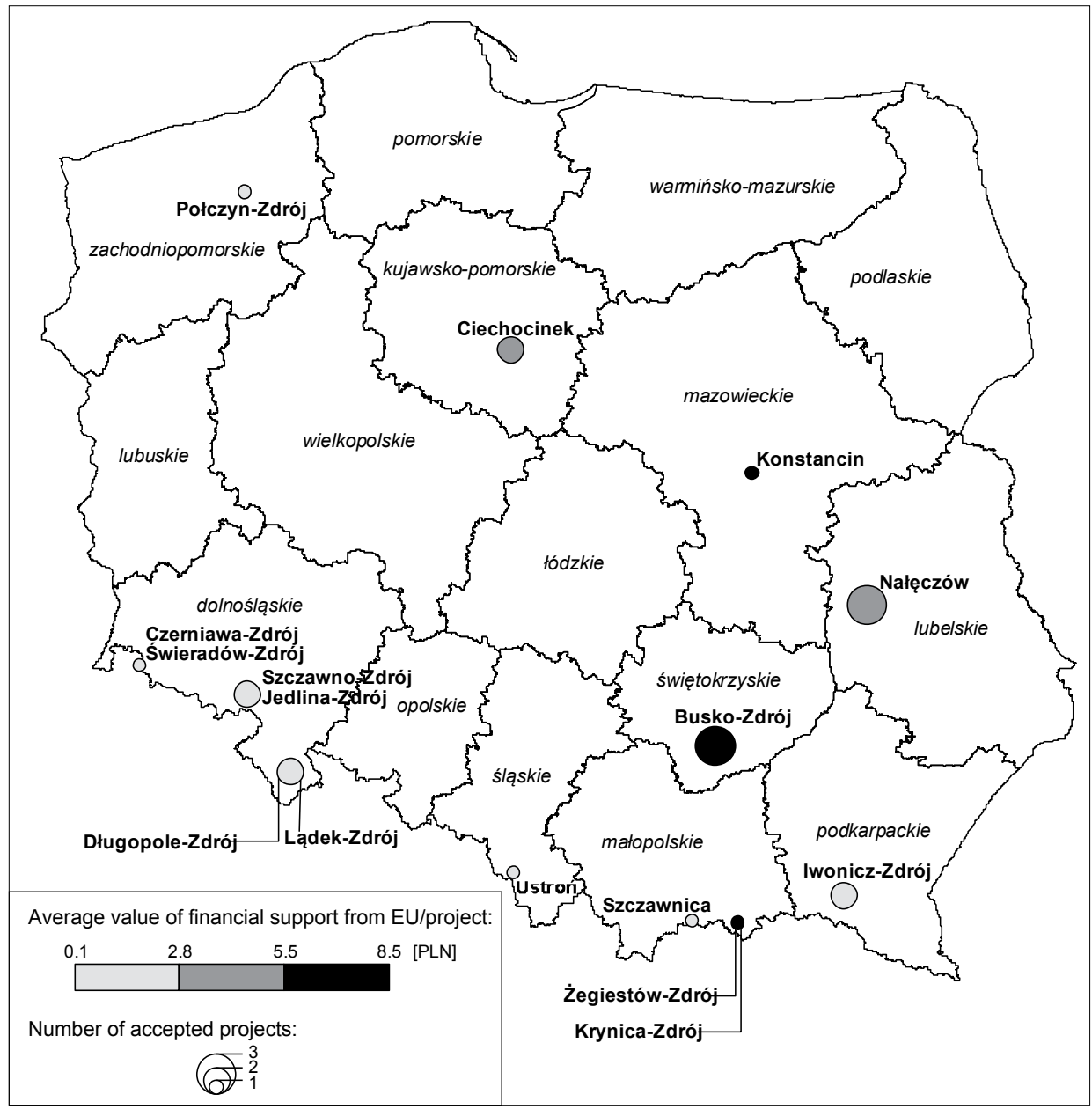

Source: authors based on EU Grants Map http://www.mapadotacji.gov.pl/

Fig. 5: Spas according to the number of projects financed and their average value

of the projects implemented $(80 \%)$ were connected with the improvement of infrastructure (building, modernisation and reconstruction). The value of the projects amounted to $68.5 \%$ of the entire EU financial support. Just two spas (Nałęczów and Szczawnica) implemented four projects in the field of modern and competitive production technologies. These spas gained more than $30 \%$ of the total value of financial support acquired. The least important factor related to the ability to acquire EU funds was geographical location. Considering the fact that some spas belong to two types and taking into account the considerable diversification within some types, it is not possible to assume that geographical location is a significant factor in acquiring EU funds. 


\section{Conclusions}

Based on this research we can conclude that

1. privatised spas were not able to raise more EU funds than spas owned by the State Treasury;

2. spas with completed privatisation and spas sold or transferred to former owners (Category 2) show considerable differences resulting from the policy of the group of spas. Spas managed by private owners (Category 2c) acquired less funds, because they have less own company capital to invest than spas being part of consortia. The latter have been the most effective, especially Nałęczów ${ }^{28)}$ investing into a project connected with Research \& Development;

3. spas belonging to the State Treasury, except Rabka, have gained significantly more EU support for the improvement of their infrastructure (especially Krynica-Żegiestów, which is excluded from sale). After they had invested, they were immediately transferred to voivodships; (At the end of November 2012, a regulation on their exclusion from privatisation was introduced and at the beginning of December the first spa was transferred without costs.)

4. a regulated legal status supports the acquisition of funds from external sources (including EU funds).

This means that our assumptions formulated in the introduction have in general been confirmed, however with one modification: A regulated legal status is an asset for fund raising not only, when it results from completed privatisation, but also when the company is guaranteed to be excluded from privatisation.

We have thereby shown that economic factors play the key role in acquiring EU funds, while location factors are of minor importance.

\section{References}

Ahas R., Aasa A., Mark Ü., Pae T., Kull A. (2007), Seasonal tourism spaces in Estonia: Case study with mobile positioning data. In: Tourism Management, 28, 3, pp. 898-910.

Ahas R., Aasa A., Roose A., Mark Ü., Silm S. (2008), Evaluating passive mobile positioning data for tourism surveys: An Estonian case study. In: Tourism Management, 29, 3, pp. 469-486.

ÁRPÁSI M. (2003), Geothermal development in Hungary - country update report 2000-2002. In: Geothermics, 32, 4-6, pp. 371-377.

Assaf A., Knežević CVelbar L. (2011), Privatisation, market competition, international attractiveness, management tenure and hotel performance: Evidence from Slovenia. In: International Journal of Hospitality Management, 30, 2, pp. 391-397.

\footnotetext{
28) A further route to EU fundraising stems from the fact that this spa resort is the oldest privatised company (since 2001). Some similarities can be noticed in the case of Szczawnica (since 2005 the property of the Stadnicki family). These resorts have completed investment in infrastructure and now may invest in very profitable productive activities, which will provide a financial source for future investment.
} 
BaChVARov M. (1997), End of the model? Tourism in post-communist Bulgaria. In: Tourism Management, 18, 1, pp. 43-50.

BAIDAL J.A.I. (2003), Regional development policies: an assessment of their evolution and effects on the Spanish tourist model. In: Tourism Management, 24, 6, pp. 655-663.

BALÁž V. (1995), Five years of economic transition in Slovak tourism; success and shortcomings. In: Tourism Management, 16, 2, pp. 143-150.

Bihari-Axelsson S., AxelsSon R. (2002), The role and effects of sanatoriums and health resorts in the Russian Federation. In: Health Policy, 59, 1, pp. 25-36.

BoruszczAK M. (ed.) (2010), Turystyka zdrowotna [Health tourism]. Gdańsk, WSTiH.

Burzyński T., Golba J., PYka J., SZYMańcZyk J. (2004), Analiza przekrojowa wybranych zagadnień związanych z turystyką uzdrowiskową. [Cross-sectional analysis of selected issues connected with spa tourism]. Krynica - Kraków, Stowarzyszenie Gmin Uzdrowiskowych RP oraz Instytut Turystyki w Krakowie Sp z o.o.

ButLer R.W. (2010), Introduction. In: SzRomeK A.R. (ed.), Uzdrowiska i ich znaczenie w gospodarce turystycznej, pp. 7-14. Kraków, Proksenia.

Carlino S., Somma R., Troise C., De Natale G. (2012), The geothermal exploration of Campanian volcanoes: Historical review and future development. In: Renewable and Sustainable Energy Reviews, 16, 1, pp. 1004-1030.

Chen K.-W., Liu H.-H., Chang F.-H. (2013), Essential customer service factors and the segmentation of older visitors within wellness tourism based on hot springs hotels. In: International Journal of Hospitality Management, 35, pp. 122-132.

COLES T. (2003), The emergent tourism industry in eastern Germany a decade after Unification. In: Tourism Management, 24, 2, pp. 217-226.

Cooper C.P., Fletcher J., Noble A., Westlake J. (1995), Changing Tourism Demand in Central Europe: The Case of Romanian Tourist Spas. In: Journal of Tourism Studies, 6, 2, pp. 30-44.

Dowgiallo J., FisteK J. (2003), New findings in the Wałbrzych-Kłodzko geothermal sub-region (Sudetes, Poland). In: Geothermics, 32, 4-6, pp. 689-699.

Dwyer L., Knežević Cvelbar L., Edwards D., Mihalič T. (2012), Fashioning a destination tourism future: the case of Slovenia. In: Tourism Management, 33, 2, pp. 305-316.

EU Grants Map. - http://www.mapadotacji.gov.pl/, last access on April 2014

FletCher J., COOPER C. (1996), Tourism strategy planning. In: Annals in Tourism Research, 23, 1, pp. 181-200.

FoISNER W. (2007), Kurarzt und Kurgast - Erwartungen und Realität [Spa doctor and spa guest expectations and reality]. In: Wiener Medizinische Wochenschrift, 157, 17-18, pp. 445-448.

Freeston D.H. (1996), Direct uses of geothermal energy 1995. In: Geothermics, 25, 2, pp. 189-214.

González M.E.A., Comesaña L.R., Brea J.A.F. (2007), Assessing tourist behavioral intentions through perceived service quality and customer satisfaction. In: Journal of Business Research, 60, 2, pp. 153-160.

Gössling S., Peeters P., Hall C.M., Ceron J.-P., Dubois G., Lehman L.V., Scott D. (2012), Tourism and water use: Supply, demand, and security. An international review. In: Tourism Management, 33, 1, pp. 1-15.

Government Regulation of 30 September 1996, Dz. U. 1996. No. 15, pos. 548, attachment no. 20.

Grose M.J. (2011), Landscape and children's health: Old natures and new challenges for the preventorium. In: Health \& Place, 17, 1, pp. 94-102.

Grzelak-Kostulska E. (2012), Wybrane problemy turystyki uzdrowiskowej w Polsce [Selected problems of health tourism in Poland]. In: Łuczak J., Szczepańska M., Bronowicki S. (eds.), Wybrane aspekty aktywności turystycznej i rekreacyjnej, pp. 209-228. Poznań, Wielkopolska Wyższa Szkoła Turystyki i Zarządzania. 
Grzelak-Kostulska E., HoŁowiecka B. (2013), Fundusze strukturalne jako czynnik stymulujący rozwój sektora turystycznego w regionie kujawsko-pomorskim [The Structural Funds as a factor stimulating development of the tourism sector in the Kuyavian-Pomeranian region]. In: Zeszyty Naukowe Uniwersytetu Szczecińskiego, Ekonomiczne Problemy Turystyki, 2, 22, pp. 73-90.

Hadzik A., Hadzik A., Mikrut G. (2009), Rola i tendencje w rozwoju uzdrowisk w Polsce [Role and trends in the development of spas in Poland] (= Wybrane zagadnienia). Kraków, Sensus.

Hadziк A., Szromek A. (2012), Prywatyzacja Zakładów Lecznictwa Uzdrowiskowego i jej implikacje społeczne [The privatisation of health resorts and its social implications] (= Zeszyty Naukowe Politechniki Śląskiej, Seria: Organizacja i Zarządzanie, 61. - http://www.woiz. polsl.pl/znwoiz/z61/Hadzik\%20SzromekA.pdf), DoA: 10.03.2014.

Haley A.J., Snaith T., Miller G. (2005), The Social Impacts of Tourism. A Case Study of Bath, UK. In: Annals of Tourism Research, 32, 3, pp. 647-668.

HOPPE A., JANICKA J., LERCH C., BRÜBACH J. (2008), Geothermal resources in the shallow, unsaturated zone of the Wiesbaden spa district, Germany. In: Geothermics, 37, 2, pp. 173-188.

Hughes H., Allen D. (2005), Cultural tourism in Central and Eastern Europe: the views of 'induced image formation agents'. In: Tourism Management, 26, 2, pp. 173-183.

Igliński B., Buczkowski R., Kujawski W., Cichosz M., Piechota G. (2012), Geoenergy in Poland. In: Renewable and Sustainable Energy Reviews, 16, 5, pp. 2545-2557.

Informacja o bieżącej sytuacji oraz prywatyzacji uzdrowiskowych spółek Skarbu Państwa [Information on the current situation and the privatisation of Polish spa resorts owned by the State Treasury]. MSP, Warszawa 2008, pp. 6-7.- http://ww2 senat.pl/k7/dok/sten/oswiad/klimowicz/1402o.pdf, DoA: 10.03.2014.

Informacja o wynikach kontroli przekształceń własnościowych zakładów lecznictwa uzdrowiskowego [Information on the control of the ownershipchanges of spa resorts]. Warszawa, Supreme Audit Office/Najwyższa Izba Kontroli, December 2002, p. 25. - http://www.nbportal. pl/library/pub_auto_B_0009/KAT_B3707.PDF, DoA: 10.03.2014.

Informacja o wynikach kontroli realizacji strategii prywatyzacji uzdrowiskowych spółek Skarbu Państwa [Information on the results of control concerning the implementation of privatisation strategy of spa resorts owned by the State Treasury]. NIK, Warszawa, January 2010.

Iorio M., Corsale A. (2010), Rural tourism and livelihood strategies in Romania. In: Journal of Rural Studies, 26, 2, pp. 152-162.

Joksimović M., Pavlović M.A. (2014), Conditions and possibilities of direct utilisation of thermal-mineral waters in Raška region, Serbia. In: Renewable and Sustainable Energy Reviews, 32, pp. 107-113.

JoNES E.L. (2013), Gentry culture and the stifling of industry. In: The Journal of Socio-Economics, 47, pp. 185-192.

KAPCZYŃSKi A., SzromeK A.R. (2008), Hypotheses concerning the development of Polish spas in the years 1949-2006. In: Tourism Management, 29, 5, pp. 1035-1037.

KAŹMIERCZAK A. (2013), Infrastruktura uzdrowiskowa w latach 1989-2012 ze szczególnym uwzględnieniem Dolnego Śląska - problemy z jej wykorzystaniem po transformacji ustrojowej i nowe szanse rozwoju [Spa infrastructure in the years 1989-2012 with particular emphasis on Lower Silesia - Problems with its use after the political transformation and new opportunities]. In: PŁonKa-Syroka B., Kaźmierczak A. (eds.), Kultura uzdrowiskowa na Dolnym Śląsku w kontekście europejskim, 2, pp. 355-382. Wrocław, Quaestio. - http://depot.ceon.pl/bitstream/ handle/123456789/3261/infrastruktura.pdf? sequence=1, DoA: 10.03.2014.

KEPINSKA B. (2003), Current state and prospects of geothermalenergy implementation in Poland. In: Applied Energy, 74, 1-2, pp. 43-51. 
Košić K., Pivac T., Romelić J., Lazić L., Stojanović V. (2011), Characteristics of thermal mineral waters in Bačka region (Vojvodina) and their exploitation in spa tourism. In: Renewable and Sustainable Energy Reviews, 15, 1, pp. 801-807.

KozŁowska B., WalenciK A., Dorda J., ZiPPER W. (2010), Radon in ground water and dose estimation for inhabitants in Spas of the Sudety Mountain area, Poland. In: Applied Radiation and Isotopes, 68, 4-5, pp. 854-857.

Krajowy Rejestr Sądowy [National Court Register]. Available at: http://www.ems.ms.gov.pl/krs/ wyszukiwaniepodmiotu, last access in April 2014.

ŁaCH K., RutKowsKa J. (2008), Raport o sytuacji ekonomiczno-finansowej spółek nadzorowanych przez Ministra Skarbu Państwa z co najmniej 25\% udziałem Skarbu Państwa w kapitale zakładowym w 2006 roku [Report on economic and financial companies supervised by the Ministry of the Treasury of at least $25 \%$ owned by the Treasury in the share capital in 2006]. Warszawa, Ministerstwo Skarbu Państwa.

ŁACH K., RUTKOwSKa J. (2010), Raport o sytuacji ekonomiczno-finansowej spółek nadzorowanych przez Ministra Skarbu Państwa z co najmniej 25\% udziałem Skarbu Państwa w kapitale zakładowym w 2008 roku [Report on economic and financial companies supervised by the Ministry of the Treasury of at least $25 \%$ owned by the Treasury in the share capital in 2008]. Warszawa, Ministerstwo Skarbu Państwa. Available at: http://www. msp.gov.pl, DoA: 10.03 .2014 .

LewandowsKa A. (2007), Turystyka uzdrowiskowa. Materiały do studiowania [Spa tourism. Study materials]. Szczecin, Wydawnictwo Naukowe Uniwersytetu Szczecińskiego.

Lewandowska A. (2008), Turystyka uzdrowiskowa [Spa tourism]. In: Panasiuk A. (ed.), Gospodarka Turystyczna, pp. 231-235. Warszawa, PWN.

Light D., Dumbrăveanu D. (1999), Romanian tourism in the post-communist period. In: Annals of Tourism Research, 26, 4, pp. 898-927.

Lund J.W. (1997), Direct heat utilization of geothermal resources. In: Renewable Energy, 10, 2-3, pp. 403-408.

Lund J.W. (2003), Direct-use of geothermal energy in the USA. In: Applied Energy, 74, 1-2, pp. $33-42$.

Lund J.W., FREESTON D.H. (2001), World-wide direct uses of geothermal energy 2000. In: Geothermics, 30, 1, pp. 29-68.

Lund J.W., Freeston D.H., Boyd T.L. (2011), Direct utilization of geothermal energy 2010 worldwide review. In: Geothermics, 40, 3, pp. 159-180.

Mayer M., Müller M., Woltering M., Arnegger J., Job H. (2010), The economic impact of tourism in six German national parks. In: Landscape and Urban Planning, 97, 2, pp. 73-82.

National Court Register. Available at: https://ems.ms.gov.pl/krs/wyszukiwaniepodmiotu? $t: l b=t$, last access on April 2014.

Omulecki A., Nowak A., Zalewska A. (1996), Spa therapy in Poland. In: Clinics in Dermatology, 14, 6, pp. 679-683.

ÖZEN T., BÜLBÜL A., TARCAN G. (2012), Reservoir and hydrogeochemical characterizations of geothermal fields in Salihli, Turkey. In: Journal of Asian Earth Sciences, 60, pp. 1-17.

ÖZKAYNAK B. (2008), Globalisation and local resistance: Alternative city developmental scenarios on capital's global frontier - the case of Yalova, Turkey. In: Progress in Planning, 70, 2, pp. 45-97.

Pendlebury J., Short M., While A. (2009), Urban World Heritage Sites and the problem of authenticity. In: Cities, 26, 6, pp. 349-358.

Petraccia L., Liberati G., Masciullo S.G., Grassi M., Fraioli A. (2006), Water, mineral water and health. In: Clinical Nutrition, 25, 3, pp. 377-385. 
Polska norma PN-Z-11000:2001 „Uzdrowiska - terminologia, klasyfikacja i wymagania ogólne” [Polish norm PN-Z-11000:2001 "Spa resorts - terminology, classification, and general requirements"].

Pozo M., Carretero M.I., Maraver F., Pozo E., Gómez I., Armijo F., Rubí, J.A.M. (2013), Composition and physico-chemical properties of peloids used in Spanish spas: A comparative study. In: Applied Clay Science, 83-84, pp. 270-279.

Prunk A., Azman J., Frkovic V., Skrobonja A., Muzur, A. (2008), Physician Albin Eder and his contribution to the development of health resorts in the Northern Adriatic area. In: Public Health, 122, 10, pp. 1131-1133.

Public Information Bulletin. Available at: http://www.bip.gov.pl/, last access on April 2014.

Routh H.B., Bhowmik K.R., Parish L.C., Witkowski, J.A. (1996), Balneology, mineral water, and spas in historical perspective. In: Clinics in Dermatology, 14, 6, pp. 551-554.

Rozporządzenie Ministra Skarbu w sprawie wykazu zakładów lecznictwa uzdrowiskowego prowadzonych w formie jednoosobowych spółek Skarbu Państwa, które nie będą podlegać prywatyzacji [Regulation of the Ministry of State Treasury of 20 July 2007 on the list of spa resorts operating as the one-man companies of the State Treasury and excluded from the privatisation], Dz.U. No. 146, pos. 1026, attachment.

Rozporządzenie Ministra Skarbu w sprawie wykazu zakładów lecznictwa uzdrowiskowego prowadzonych w formie jednoosobowych spółek Skarbu Państwa, które nie będą podlegać prywatyzacji [Regulation of the Ministry of State Treasury of 8 October 2008 on the list of spa resorts operating as the one-man companies of the State Treasury and excluded from the privatisation], Dz.U. No. 192, pos. 1186, attachment.

Rozporządzenie Ministra Skarbu w sprawie wykazu zakładów lecznictwa uzdrowiskowego prowadzonych w formie jednoosobowych spółek Skarbu Państwa, które nie będą podlegać prywatyzacji [Regulation of the Ministry of State Treasury of 29 November 2012 on the list of spa resorts operating as the one-man companies of the State Treasury and excluded from the privatisation], Dz.U. 2012, pos. 1332, attachment.

Samsudin A.R., Hamzah U., Rahman R.A., Siwar C., Mohd M.F., Othman R. (1997), Thermal springs of Malaysia and their potential development. In: Journal of Asian Earth Sciences, 15, 2-3, pp. 275-284.

Seckelmann A. (2002), Domestic tourism - a chance for regional development in Turkey? In: Tourism Management, 23, 1, pp. 85-92.

Sekine M., Nasermoaddeli A., Wang H., Kanayama H., Kagamimori S. (2006), Spa resort use and health-related quality of life, sleep, sickness absence and hospital admission: The Japanese civil servants study. In: Complementary Therapies in Medicine, 14, 2, pp. 133-143.

Snoj B., Mumel D. (2002), The measurement of perceived differences in service quality - the case of health spas in Slovenia. In: Journal of Vacation Marketing, 8, 4, pp. 362-379.

Środa-MurawsKa S. (2012), Miasta uzdrowiskowe w Polsce w ujęciu wielkości i struktury bazy obiektów zbiorowego zakwaterowania [Spas in Poland in terms of size and structure as documented by the database of collective accommodation facilities]. In: RYDZ E. (ed.), Ekonomiczne i organizacyjne aspekty funkcjonowania polskich uzdrowisk, pp. 21-29. Słupsk, Wydawnictwo Akademii Pomorskiej.

Ustawa o komercjalizacji i prywatyzacji przedsiębiorstw państwowych [Act on the Commercialisation and Privatisation of State Enterprises of 30 August 1996], Dz.U. 1996, No. 118, pos. 561.

Ustawa o lecznictwie uzdrowiskowym, uzdrowiskach i obszarach ochrony uzdrowiskowej oraz o gminach uzdrowiskowych [Act on Spa Treatment, Spa Resorts and Areas of Spa Protection of 28 July 2005], Dz.U. 2005, No. 167, pos. 1399. 
Ustawa o prywatyzacji przedsiębiorstw państwowych [Act on the Privatisation of State Enterprises of 13 July 1990], Dz.U. 1990, No. 51, pos. 298.

Voronov A.N. (2000), Some features of mineral waters in Russia. In: Environmental Geology, 39, 5, pp. 477-481.

Voronov A.N., VinOgRad Ć.N.A. (2009), The Lower-Kotlin aquifer as a source of mineral therapeutic waters for St. Petersburg. In: Environmental Earth Sciences, 59, 1, pp. 15-20.

W ALENCIK A. KoZŁowsKa B, DoRda J., ZiPPER W. (2010), Natural radioactivity in underground water from the Outer Carpathians in Poland with the use of nuclear spectrometry techniques. In: Applied Radiation and Isotopes, 68, 4-5, pp. 839-843.

WoŁowIEC T. (2001), Proces prywatyzacji i komercjalizacji uzdrowiskowych zakładów opieki zdrowotnej [The process of privatisation and commercialisation of spa and healthcare facilities]. In: Biuletyn Stowarzyszenia Gmin Uzdrowiskowych RP, 3, pp. 61-67.

WoŁowiEc T. (2003), Bariery finansowe i legislacyjne rozwoju polskich gmin uzdrowiskowych w perspektywie integracji z Unią Europejską [Financial barriers and the legislative development of Polish health resort municipalities in the perspective of integration into the European Union]. In: Studia Regionalne i Lokalne, 3, 13, pp. 97-107. Available at: http://www. studreg.uw.edu.pl/pdf/2003_3_wolowiec.pdf, DoA: 10.03.2014.

WoŁowIEC T. (2005), Konkurencyjność polskich gmin uzdrowiskowych w warunkach integracji z Unią Europejską [The competitiveness of Polish health resort municipalities in the process of integration into the European Union]. In: Roczniki Nauk Społecznych - Ekonomia i Zarządzanie, XXXIII, pp. 165-191.

Załącznik do ustawy budżetowej na rok 2000 z dnia 21 stycznia 2000 r., Dz.U. No 7, pos. 85; uzasadnienie do projektu ustawy budżetowej na rok 2001 - druk sejmowy $\mathrm{nr} 2371 \mathrm{z}$ dnia 15 listopada 2000 r., uzasadnienie do projektu ustawy budżetowej na rok 2002 - druk sejmowy $\mathrm{nr} 87 \mathrm{z}$ dnia 26 listopada $2001 \mathrm{r}$. [Attachment to the Act on the State Budget for the year of 2000 - from 21 January 2000].

Zintegrowany Program Rozwoju Uzdrowisk ze szczególnym uwzględnieniem usług turystycznych [Integrated Programme of Spa Resort Development with the special consideration of tourist services]. Warszawa, Międzyresortowy Zespół ds. Aktywizacji Społeczno-Gospodarczej Uzdrowisk 2005. 